\title{
Article \\ Cytomegalovirus Serostatus and Functional Impairment in Liver Transplant Recipients in the Current Era
}

\author{
Nina Singh * and Marilyn M. Wagener
}

check for updates

Citation: Singh, N.; Wagener, M.M. Cytomegalovirus Serostatus and Functional Impairment in Liver Transplant Recipients in the Current Era. Viruses 2021, 13, 1519.

https://doi.org/10.3390/v13081519

Academic Editor: Thomas

Stamminger

Received: 8 July 2021

Accepted: 29 July 2021

Published: 1 August 2021

Publisher's Note: MDPI stays neutral with regard to jurisdictional claims in published maps and institutional affiliations.

Copyright: (c) 2021 by the authors. Licensee MDPI, Basel, Switzerland. This article is an open access article distributed under the terms and conditions of the Creative Commons Attribution (CC BY) license (https:// creativecommons.org/licenses/by/ $4.0 /)$.
University of Pittsburgh and Veterans Affairs Pittsburgh Healthcare System, Pittsburgh, PA 15240, USA; mmw5@pitt.edu

* Correspondence: nis5@pitt.edu

\begin{abstract}
Background: Whether donor (D+) or recipient $(\mathrm{R}+)$ cytomegalovirus (CMV) seropositivity is associated with functional impairment in liver transplant recipients is not known. Methods: Patients included adult liver transplant recipients in the Organ Procurement and Transplantation Network database transplanted over a five-year period from 1 January 2014-31 December 2018. Functional status in the database was assessed using Karnofsky performance scale. A logistic regression model that controlled for potential confounders was used to examine the association of CMV serostatus and functional status. Variables significantly associated with functional status $(p<0.05)$ were then used to develop propensity score and propensity score matched analysis was conducted where each patient was compared with a matched-control with the same propensity score. Results: Among 30,267 adult liver transplant recipients, D+ or $\mathrm{R}+$ patients had significantly lower functional status at last follow-up than the D-R- cohort (OR 0.88, 95\% CI 0.80-0.96, $p=0.007$ ). In propensity score matched model, $\mathrm{D}+$ or $\mathrm{R}+$ patients had significantly lower functional status than matched-controls $(p=0.009)$. D+ or $\mathrm{R}+\mathrm{CMV}$ serostatus $(p=0.018)$ and low functional level $(p<0.001)$ were also independently associated with infections as cause-of-death. Conclusions: $\mathrm{D}+\mathrm{or} \mathrm{R}+$ liver transplant recipients had lower functional status and higher risk of deaths due to infections. Future studies are warranted to examine the mechanistic basis of these findings in the setting of transplantation.
\end{abstract}

Keywords: cytomegalovirus; transplant; outcomes; functional status

\section{Introduction}

Cytomegalovirus (CMV) has long been recognized as a major opportunistic pathogen in organ transplant recipients [1,2]. In addition to overt disease, there are indirect effects of CMV which include rejection, graft loss, opportunistic infections, vascular thrombosis, and new onset diabetes that may contribute to the excess deaths [3]. Although the adverse effects of CMV on the outcomes after transplantation have diminished in the current era of antiviral prophylaxis, CMV continues to have a major negative impact on posttransplant outcomes.

Epidemiologic studies in the general population have documented an association between CMV seropositive status and functional impairment, cognitive decline, and frailty that interfere with or limit normal functioning and activities of daily living [4,5]. CMV seropositivity is indicative of latent state of the virus during which subclinical and low-level replication occurs throughout the lifetime of an individual [6]. The persistent antigen exposure and resultant low-grade inflammatory state has the potential to accelerate host cell and tissue damage leading to frailty, progression of aging and ultimately death [6,7]. Comprehensive assessment of immune profiling in a large cohort of healthy aging adults showed that CMV serostatus was among the factors with most impact on immune dysfunction with aging [8].

In kidney transplant recipients, lower functional status and frailty increased the risk of adverse outcomes including delayed graft function, early hospital readmission, cognitive decline, and mortality [9-12]. Lower functional status has also been associated 
with higher mortality in simultaneous kidney pancreas recipients [13], liver transplant recipients [14], as well as lung transplant recipient $[15,16]$. An estimated $25 \%$ of liver transplant candidates are deemed frail and frailty conferred a higher risk of wait-list long-term mortality, increased hospitalizations, and depression [17]. However, to our knowledge, there are no studies that have systematically examined the association between CMV serostatus and functional status after liver transplantation in a large cohort of patients. Using the Organ Procurement and Transplantation Network (OPTN) database, we sought to determine if CMV seropositivity in the donor or the recipient was associated with functional impairment in liver transplant recipients.

\section{Methods}

Data for the study were obtained from the OPTN and Standard Transplant Analysis and Research (STAR) database, a national registry that includes data on all organ transplants performed in the US since 1987. The United Network of Organ Sharing (UNOS) under the U.S. Department of Health and Human Services maintains oversight of OPTN. Patients included in this study were liver transplant recipients $\geq 18$ years of age undergoing transplantation in the 5-year period between January 2014 and December 2018 (both years inclusive), with at least one year of follow-up and for whom recipient and donor CMV serostatus and functional status post-transplant was available. This time-period was selected so as to be most reflective of contemporary management practices after liver transplantation. Additionally, while functional status was available on $88 \%$ of the patients from 2014-2018; functional status availability was less than 50\% prior to 2014 . Functional status in the OPTN database is evaluated by the Karnofsky performance scale which assesses the ability to perform daily activities and the level of assistance required in doing so [18]. This comprehensive tool measures patient's functional level on an 11point scale ranging from a score of 100 (normal functioning) to 0 (dead) in ten-point increments $[14,19,20]$ (Table 1). A score of $\geq 80$ is considered indicative of normal functional status [18]. Institutional review board of the VA Pittsburgh Healthcare System approved the study under exempt category as this is a publicly available de-identified dataset.

Table 1. Karnofsky performance scale.

\begin{tabular}{|c|c|c|}
\hline Activity Level & Score & Description \\
\hline \multirow{3}{*}{$\begin{array}{l}\text { Able to carry on normal } \\
\text { activity and to work; no } \\
\text { special care needed }\end{array}$} & 100 & Normal, no complaints; no evidence of disease \\
\hline & 90 & $\begin{array}{l}\text { Able to carry on normal activity; minor signs or } \\
\text { symptoms of disease }\end{array}$ \\
\hline & 80 & $\begin{array}{l}\text { Normal activity with effort; some signs and } \\
\text { symptoms of disease }\end{array}$ \\
\hline \multirow{3}{*}{$\begin{array}{l}\text { Unable to work; able to live at } \\
\text { home and care for most } \\
\text { personal needs; varying } \\
\text { amount of assistance needed }\end{array}$} & 70 & $\begin{array}{l}\text { Cares for self; unable to carry on normal activity } \\
\text { or do active work }\end{array}$ \\
\hline & 60 & $\begin{array}{l}\text { Requires occasional assistance but is able to care } \\
\text { for most personal needs }\end{array}$ \\
\hline & 50 & $\begin{array}{l}\text { Requires considerable assistance and frequent } \\
\text { medical care }\end{array}$ \\
\hline \multirow{5}{*}{$\begin{array}{l}\text { Unable to care for self; } \\
\text { requires equivalent of } \\
\text { institutional or hospital care; } \\
\text { disease may be } \\
\text { progressing rapidly }\end{array}$} & 40 & Disabled; requires special care and assistance \\
\hline & 30 & $\begin{array}{l}\text { Severely disables; hospital admission is } \\
\text { indicated although death not imminent }\end{array}$ \\
\hline & 20 & $\begin{array}{l}\text { Very sick; hospital admission necessary; active } \\
\text { supportive treatment necessary }\end{array}$ \\
\hline & 10 & Moribund; fatal process progressing rapidly \\
\hline & 0 & Dead \\
\hline
\end{tabular}

\section{Statistical Analyses}

Stata/SE, version 16.1 (Stata Corp, College Station, TX, USA) was used for all statistical analysis. The primary goal of the study was to determine whether CMV seropositive status of the recipient $(\mathrm{R}+)$ or the donor $(\mathrm{D}+)$ was associated with functional impairment after 
transplantation. A logistic regression model was used to assess functional status at last follow-up and CMV serostatus as the predictor. To account for potential imbalances in clinical characteristics, severity of illness or other confounders, additional risk factors such as age, underlying liver disease, model of end stage liver disease (MELD) score, comorbidities at the time of transplant and years of follow-up were included in the model. Variables found to be significantly associated with functional status in logistic regression model $(p<0.05)$ were then used to develop a propensity score and propensity score matching analysis was conducted. For each patient, the model identifies a matched-control with similar propensity score and mathematically accounts for any bias in the probability of the outcome, which was normal functioning status, a binary endpoint. The CMV-specific effect in the model was computed by evaluating the average of the difference between the observed outcome in CMV seropositive patient and the projected outcome in the matched-control.

Both CMV serostatus and functional status were evaluated for their association with survival. Kaplan-Meier survival functions were calculated for each of four CMV serostatus groups (D+R+, D+R-, D-R+, D-R-). The log-rank test was used to assess for equality between the four survival functions. Functional status at last follow-up was also evaluated with a logistic model with the end point of all-cause mortality. The model included risk factors that may portend poor outcome in liver transplant recipients such age, MELD score, dialysis, and allograft rejection. An additional analysis was performed for assessment of deaths due to infections. Deaths attributed to infections included items coded as bacterial peritonitis, pneumonia, generalized sepsis, fungal and viral infections in the registry database. Infection as a cause-of-death was examined using a competing-risk survival regression model

\section{Results}

There were 30,267 liver transplant recipients in the OPTN/UNOS database who were transplanted within the protocol-specified period with known donor and recipient CMV serostatus and for whom functional status was available. Of these, $40.1 \%(12,150)$ were $\mathrm{D}+\mathrm{R}+, 22.1 \%$ (6676) were $\mathrm{D}-\mathrm{R}+, 22.8 \%$ (6896) were $\mathrm{D}+\mathrm{R}$ - and $15.0 \%$ (4545) were D-R(Table 2). All patients had $>1$ year of post-transplant follow-up; the median follow-up was 2.2 years and ranged from 1-12 years. The median MELD score was 22 (IQR 14-32); $30.1 \%$ (9108) of the patients had MELD $\geq 30$ (Table 2). Overall, 16.6\% (5012) of the patients required renal replacement therapy, and $4 \%$ (1213) were on life support at the time of transplantation (Table 2).

\subsection{Functional Status}

In total, $71.9 \%$ of the patients at the end of first post-transplant year had normal functioning, $10.7 \%$ were capable of self-care but unable to carry on normal activity, $6.6 \%$ required occasional or frequent assistance, and $10.8 \%$ were disabled (Table 3). Average functional status by CMV serostatus over the study period showed that D-R-cohort had the highest functional level, followed by $\mathrm{D}-\mathrm{R}+, \mathrm{D}+\mathrm{R}-$ and $\mathrm{D}+\mathrm{R}+$ patients (who had the lowest level of functioning) (Figure 1). D-R+, D+R- and D+R+ groups all had significantly lower functional status than D-R- patients ( $p<0.005$ for each comparison) (Figure 1 ). 
Table 2. Demographic and clinical characteristics of the 30,267 study patients.

\begin{tabular}{|c|c|c|}
\hline \multicolumn{2}{|l|}{ Variable } & Number of Patients, $n / n(\%)$ \\
\hline \multicolumn{3}{|c|}{ Demographic Data } \\
\hline \multicolumn{3}{|l|}{ Recipient } \\
\hline Age: & $\begin{array}{l}\text { Median }\left(\mathrm{IQR}^{1}\right) \\
>65 \text { years }\end{array}$ & $\begin{array}{l}58(50-64) \\
6252(20.7 \%)\end{array}$ \\
\hline Gender: & $\begin{array}{l}\text { Male } \\
\text { Female }\end{array}$ & $\begin{array}{l}19,886(65.7 \%) \\
10,381(34.3 \%)\end{array}$ \\
\hline Race: & $\begin{array}{l}\text { White } \\
\text { Hispanic } \\
\text { African-American } \\
\text { Asian } \\
\text { Other/unknown }\end{array}$ & $\begin{array}{l}21,469(70.9 \%) \\
4293(14.2 \%) \\
2772(9.2 \%) \\
1249(4.1 \%) \\
484(1.6 \%)\end{array}$ \\
\hline \multicolumn{3}{|l|}{ Donor } \\
\hline Age: & $\begin{array}{l}\text { Median }\left(\mathrm{IQR}^{1}\right) \\
>65 \text { years }\end{array}$ & $\begin{array}{l}40(27-53) \\
2224(7.4 \%)\end{array}$ \\
\hline Gender: & $\begin{array}{l}\text { Male } \\
\text { Female }\end{array}$ & $\begin{array}{l}18,041(59.6 \%) \\
12,226(40.4 \%)\end{array}$ \\
\hline \multicolumn{2}{|c|}{ Cause-of-death: Trauma } & $8582(28.4 \%)$ \\
\hline \multicolumn{3}{|c|}{ Medical history } \\
\hline $\begin{array}{l}\text { Underlyir } \\
\text { Hepatitis } \\
\text { Alcoholic } \\
\text { Non-alco } \\
\text { Cryptoge } \\
\text { Hepatoce }\end{array}$ & & $\begin{array}{l}6995(23.1 \%) \\
7402(24.5 \%) \\
4561(15.1 \%) \\
1257(4.2 \%) \\
8512(28.1 \%)\end{array}$ \\
\hline \multicolumn{2}{|c|}{ Diabetes mellitus } & $8516(28.1 \%)$ \\
\hline \multicolumn{2}{|c|}{ Renal replacement therapy at transplant } & $5012(16.6 \%)$ \\
\hline \multicolumn{2}{|c|}{ MELD $^{3}$ score, median (IQR) } & $\begin{array}{l}22(14-32) \\
9108(30.1 \%)\end{array}$ \\
\hline \multicolumn{2}{|c|}{ On life support } & $1213(4.0 \%)$ \\
\hline \multicolumn{3}{|c|}{ Donor and recipient CMV serostatus } \\
\hline \multicolumn{2}{|l|}{$\begin{array}{l}\text { D+R- } \\
\text { D+R+ } \\
\text { D-R+ } \\
\text { D-R- }\end{array}$} & $\begin{array}{l}6896(22.8 \%) \\
12,150(40.1 \%) \\
6676(22.1 \%) \\
4545(15.0 \%)\end{array}$ \\
\hline
\end{tabular}

${ }^{1} \mathrm{IQR}=$ Interquartile range; ${ }^{2}$ May have more than one underlying diseases; Table lists top five underlying diseases $;^{3}$ MELD $=$ Model for end stage liver disease.

Table 3. Functional status in study patients by the year of transplant.

\begin{tabular}{|c|c|c|c|c|c|}
\hline \multirow{2}{*}{$\begin{array}{l}\text { Transplant } \\
\text { Year (Years of } \\
\text { Follow-Up) }\end{array}$} & \multirow{2}{*}{$\begin{array}{l}\text { Number of } \\
\text { Patients at } \\
\text { Each Year }\end{array}$} & \multicolumn{4}{|c|}{ Number of Patients with Specified Functional Status } \\
\hline & & $\begin{array}{c}\text { Normal } \\
\text { Functioning }\end{array}$ & $\begin{array}{l}\text { Capable of } \\
\text { Self-Care }{ }^{1}\end{array}$ & $\begin{array}{l}\text { Requiring } \\
\text { Assistance } 1\end{array}$ & Disabled $^{1}$ \\
\hline $2014(5)$ & 5091 & 3568 (70.1\%) & $467(9.2 \%)$ & $333(6.5 \%)$ & $723(14.2 \%)$ \\
\hline $2015(4)$ & 5479 & $3980(72.6 \%)$ & $483(8.8 \%)$ & $363(6.6 \%)$ & $653(11.9 \%)$ \\
\hline $2016(3)$ & 6304 & $4546(72.11 \%)$ & $640(10.2 \%)$ & $400(6.4 \%)$ & 718 (11.4\%) \\
\hline $2017(2)$ & 6536 & $4798(73.4 \%)$ & $710(10.9 \%)$ & $434(6.6 \%)$ & $594(9.1 \%)$ \\
\hline $2018(1)$ & 6857 & $4868(72.6 \%)$ & $928(13.5 \%)$ & $481(7.0 \%)$ & $580(8.5 \%)$ \\
\hline
\end{tabular}

Data are shown for all patients with complete 1-year follow-up. Functional level was assessed by Karnofsky performance score at most recent follow-up. ${ }^{1}$ Normal function (80-100), capable of selfcare (70), requires assistance (50-60), disabled (10-40). 


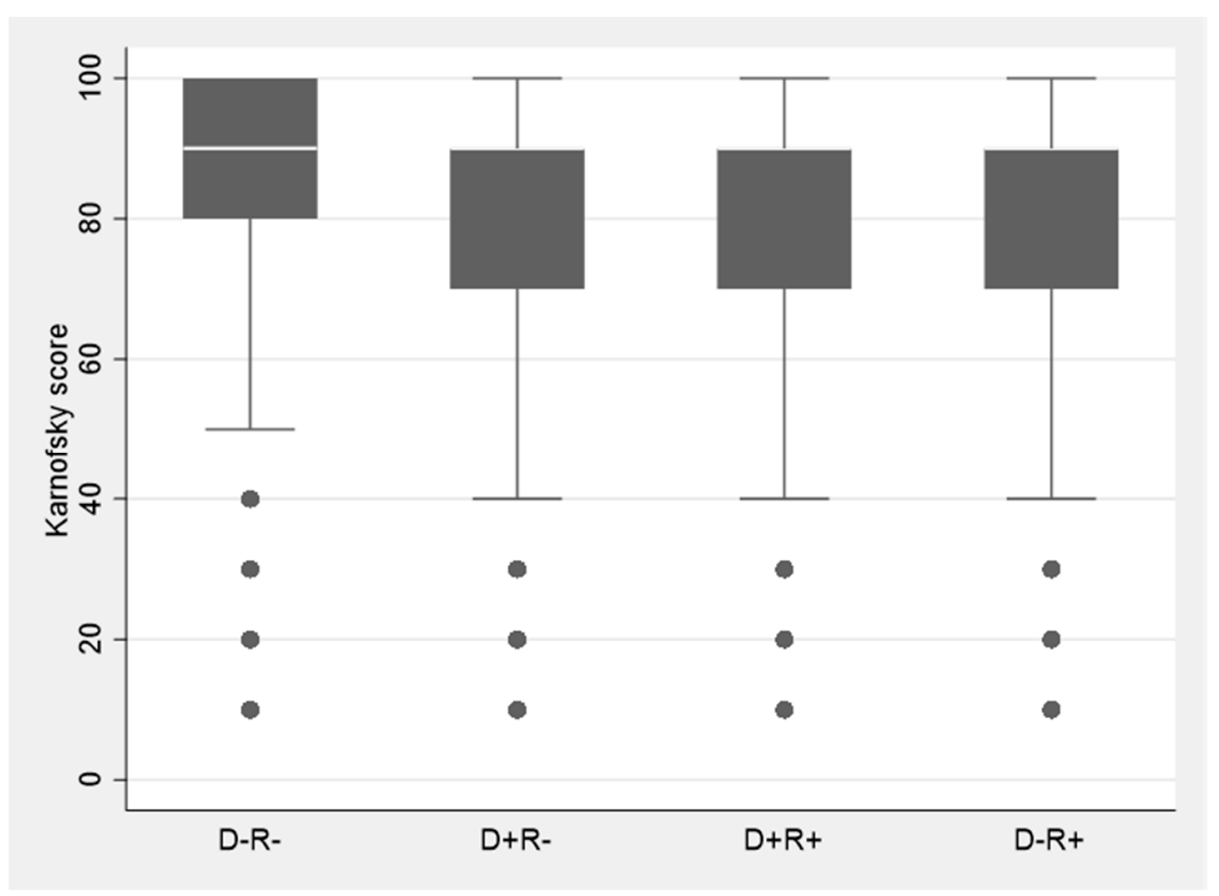

Figure 1. Functional status in each of four donor and recipient CMV serostatus groups. $\mathrm{D}=$ donor, $\mathrm{R}=$ recipient. CMV D-R-patients had the highest while $\mathrm{D}+\mathrm{R}+$ had the lowest functional level. $\mathrm{D}+\mathrm{R}-$, $\mathrm{D}+\mathrm{R}+, \mathrm{D}-\mathrm{R}+$ each had significantly lower Karnofsky score than D-R- patients $(p<0.005)$.

In logistic regression model, $\mathrm{D}+$ or $\mathrm{R}+\mathrm{CMV}$ serostatus was independently associated with lower functional status at last follow-up (odds ratio $0.88,95 \%$ CI $0.81-0.95, p=0.001$ ) even when controlled for recipient and donor age, comorbidities at transplantation (MELD, diabetes, need dialysis, need for life support), allograft rejection, and year of transplantation (Table 4). In propensity score matched sample analysis (where each patient was matched with a control with above recipient and donor properties), CMV seropositivity was significantly associated with lower functional level at last follow-up $(p=0.009)$ (Table 5).

Table 4. Factors associated with normal functional status ${ }^{1}$ at last follow-up.

\begin{tabular}{llll}
\hline \multicolumn{1}{c}{ Variable } & \multicolumn{1}{c}{ Reference Group } & Odds Ratio (95\% CI) & $p$-Level \\
\hline D+ or R+ serostatus & D-R- & $0.88(0.81-0.95)$ & 0.001 \\
\hline Recipient age $\geq$ 65 years & Recipient age $<65$ years & $0.87(0.82-0.94)$ & $<0.001$ \\
\hline Donor age $\geq 65$ years & Donor age $<65$ years & $0.80(0.72-0.88)$ & $<0.001$ \\
\hline MELD $\geq 30$ & MELD <30 & $0.94(0.87-1.01)$ & 0.089 \\
\hline Underlying liver disease & Other liver disease & $0.86(0.80-0.91)$ & $<0.001$ \\
Hepatitis C virus & & $0.95(0.89-1.02)$ & 0.172 \\
Alcohol & & $0.89(0.81-0.98)$ & 0.016 \\
Nonalcoholic hepato-steatosis & & $0.95(0.82-1.09)$ & 0.472 \\
\hline Diabetes at transplant & No diabetes & $0.78(0.74-0.83)$ & $<0.001$ \\
\hline Dialysis at transplant & No dialysis & $0.89(0.81-0.97)$ & 0.007 \\
\hline Donor cause-of-death (trauma) & Other donor cause-of-death & $1.09(1.02-1.15)$ & 0.006 \\
\hline On life support at transplant & No life support & $0.84(0.72-0.97)$ & 0.020 \\
\hline Any rejection episodes & No rejection & $0.76(0.71-0.83)$ & $<0.001$ \\
\hline Year of transplant & 2014 & $1.02(0.99-1.04)$ & 0.148 \\
\hline Normal functic & & \\
\hline
\end{tabular}

${ }^{1}$ Normal functional status $=$ Karnofsky performance score $80-100$. 
Table 5. Propensity score matched models. Patients with CMV recipient or donor seropositive status donor or recipient were significantly less likely to have normal functional status compared to matched-controls with the same propensity score.

\begin{tabular}{lcc}
\hline \multicolumn{1}{c}{ Model $^{1}$} & $\begin{array}{c}\text { Average Effect of Donor or } \\
\text { Recipient CMV Seropositivity }\end{array}$ & $p$-Level \\
\hline Complete dataset & $-7.7 \%(\mathrm{CI}-5.8$ to -9.6$)$ & 0.005 \\
\hline Subset with immunosuppression data available $^{1}$ & $-5.6 \%(\mathrm{CI}-3.8$ to -7.5$)$ & 0.011 \\
\hline
\end{tabular}

Normal functioning was defined as Karnofsky $\geq 80$. Variables included in the propensity score model were recipient and donor age, diabetes, dialysis, life support at transplant, trauma as donor cause-of-death, rejection, underlying liver disease and time post-transplant. ${ }^{1}$ The model includes subset of patients with tacrolimus as maintenance immunosuppressive therapy in addition to the above variables in the model.

Complete immunosuppression data were available on a subset of patients only $(4.6 \%$, $1390 / 30,267)$. Of these, $64 \%$ received any induction immunosuppression and received $8 \%$ T-cell depleting regimens. There was no association between receipt of T-cell depleting induction and functional status; in all $9 \%(78 / 872)$ of the patients with versus $6 \%(22 / 341)$ of those without normal functioning status received T-cell depleting induction $(p=0.156)$. Primary immunosuppressive agent consisted of tacrolimus in $83 \%$ of the patients; this subset in propensity score matched analysis also showed a significant decrease in functional status ( $p=0.001$ ), similar to the full model comprising the entire study population (Table 5).

\subsection{Mortality}

All-cause mortality was higher in the CMV seropositive recipient or donor groups when compared the D-R-group. The risk of death was 1.07 (CI 1.03-11) for D-R+, 1.15 (CI 1.11-1.19) for D+R+ and 1.14 (CI 1.10-1.18) for D+R-patients (Figure 2). Overall, the 4 CMV survival curves were significantly different $(p<0.001)$ (Figure 2). Functional impairment was significantly associated with infections as cause-of-death (Table 6). Using the last functional status prior to death, infections were the cause-of-death in $<0.1 \%(33 / 21,760)$ of the patients with normal functional status, $1.0 \%$ (33/3228) in those who could perform only self-care, $4.7 \%(95 / 2011)$ in those who required any level of assistance, and $21.1 \%$ $(690 / 3268)$ in patients who were disabled $(p<0.001)$. When controlled for MELD score, recipient and donor age, requirement for dialysis and allograft rejection, D+ or R+CMV serostatus $(p=0.018)$ was independently associated with greater risk and normal functional level with lower risk $(p<0.001)$ of death due to infections (Table 6).

Table 6. Association of functional status at last follow-up with infection as a cause-of-death in patients who died. Patients with functional impairment were significantly more likely to have infections as cause-of-death compared to those with normal functional status.

\begin{tabular}{llll}
\hline \multicolumn{1}{c}{ Characteristics } & \multicolumn{1}{c}{ Reference Group } & \multicolumn{1}{c}{ Odds Ratio (95\% CI) } & $p$-Level \\
\hline $\mathrm{D}+{ }^{1}$ or $\mathrm{R}+{ }^{2} \mathrm{CMV}^{3}$ serostatus & D-R- & $1.98(1.13-3.49)$ & 0.018 \\
\hline Capable of self-care & Normal function & $2.09(0.94-4.63)$ & 0.069 \\
Requires assistance & & $12.68(6.55-24.57)$ & $<0.001$ \\
Disabled & & $36.18(25.96-50.42)$ & $<0.001$ \\
\hline $\mathrm{MELD}^{4} \geq 30$ & MELD $<30$ & $1.24(0.87-1.76)$ & 0.238 \\
\hline Dialysis at transplant & No dialysis & $1.65(1.10-2.47)$ & 0.015 \\
\hline Recipient age $\geq 65 \mathrm{y}$ & Age $<65 \mathrm{y}$ & $1.28(0.90-1.83)$ & 0.165 \\
\hline Donor age $\geq 65 \mathrm{y}$ & Donor age $<65 \mathrm{y}$ & $2.33(1.63-3.34)$ & $<0.001$ \\
\hline Rejection & No rejection & $1.65(1.19-2.28)$ & 0.002 \\
\hline
\end{tabular}

Abbreviations: ${ }^{1} \mathrm{D}=$ donor, $^{2} \mathrm{R}=$ recipient,${ }^{3} \mathrm{CMV}=$ cytomegalovirus, ${ }^{4} \mathrm{MELD}=$ Model for end stage liver disease 


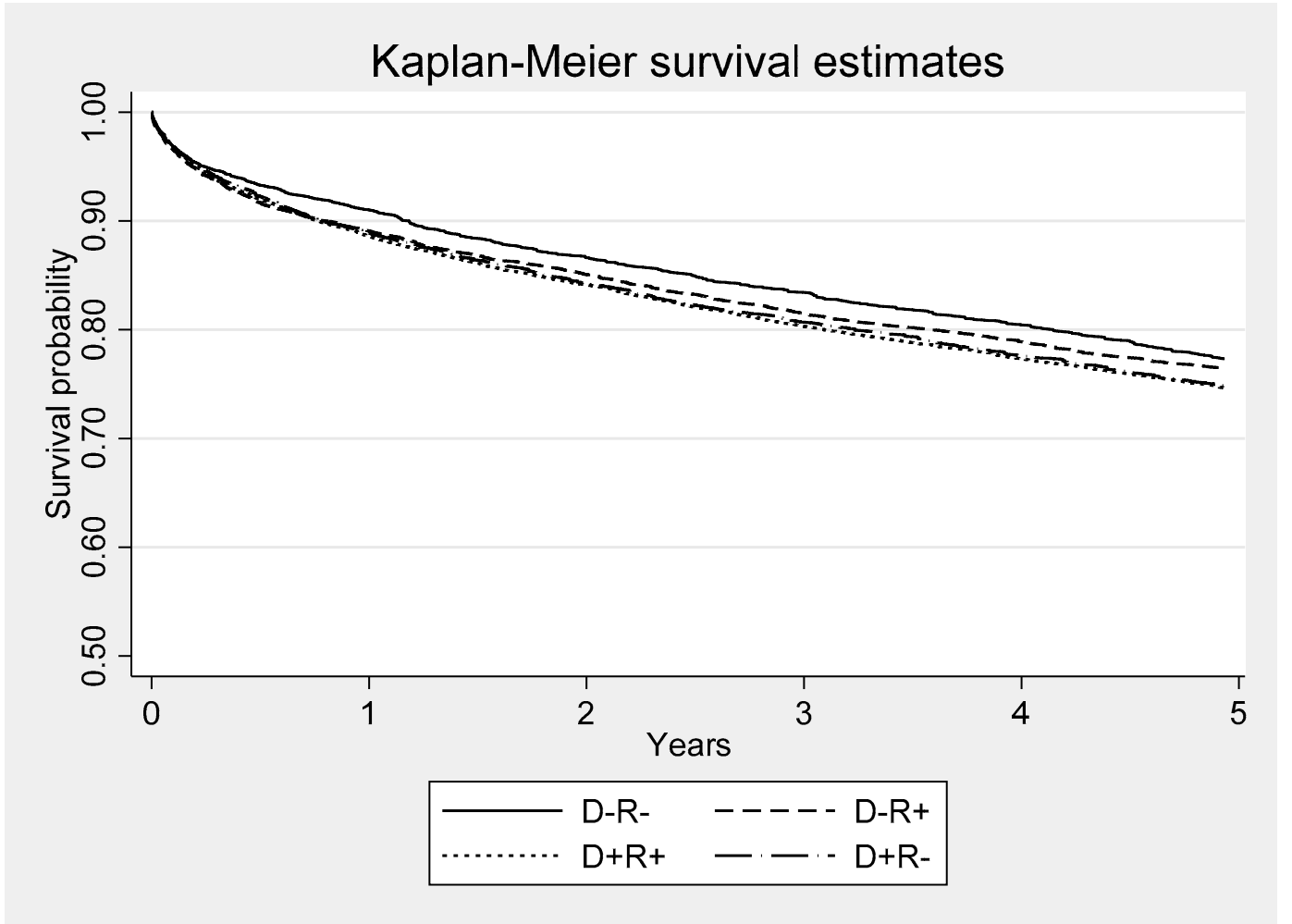

Figure 2. Kaplan-Meier survival functions for each of four donor and recipient CMV serostatus groups. D = donor; $\mathrm{R}=$ recipient. All-cause mortality was higher in the CMV seropositive recipient or donor groups when compared to D-Rgroup. The risk of death was 1.07 (CI 1.03-11) for D-R+, 1.15 (CI 1.11-1.19) for D+R+ and 1.14 (CI 1.10-1.18) for D+R. The four survival curves were significantly different $(p<0.001)$.

\section{Discussion}

Our study shows that CMV seropositivity in the donor or the recipient had a negative impact on functional status in liver transplant recipients. D+ or $\mathrm{R}+$ patients had significantly lower functional status in comparison to their contemporaneous D-R- counterparts. Although the mechanism underlying these associations is not fully understood, growing body of evidence in immunocompetent hosts suggests that latent state CMV (indicative of CMV seropositivity) may have unique role in the development of and/or acceleration of age-related frailty and functional impairment [5-7].

CMV latency is characterized by lifelong maintenance of the viral genome in the host tissues. The virus even in its transcriptionally quiescent state continues to express immediate-early genes without progression to the productive forms of the virus [21-23]. The ensuing immunostimulatory and inflammatory state triggered by chronic antigenic stimulation over time leads to host cell damage and manifestations of frailty and functional decline [6,7]. CMV antibody levels, considered to reflect multiple CMV reactivations experienced during life, correlated with cognitive decline in older individuals, even when controlled for other risk factors such as age and chronic health conditions [7].

Shorter telomere length and reduced telomerase activity have garnered significant interest as potential biomarkers of cellular aging [24,25]. Latent CMV infection has been associated with telomere shortening in the infected cells [24]. Indeed, longitudinal studies of changes in telomere length showed that CMV seropositivity added the equivalent of $\sim 12$ years of chronological age in healthy adults 53-76 years of age [26]. These data provide plausibility of our findings about the association of CMV seropositivity with longterm functional impairment. However, the mechanistic basis specifically in the setting of transplantation remains to be elucidated. 
Functional impairment also correlated significantly with infections as cause-of death in our study. Higher risk of infections may be explained in part by unique effects of CMV on host immunity with aging. Recurrent antigenic stimulation during CMV latency is characterized by progressive clonal expansion of late-differentiated CD8+ T-cells and a decline in naïve T-cells for recruitment in response to pathogens other than CMV [27-29]. Together with reduced repertoire of naïve T-cells due age-related decrease in thymic generation of precursor cells, the ability of the immune system to mount an efficient response against other pathogens and foreign antigens may be compromised rendering the host susceptible to a variety of bacterial and viral infections as well as non-infectious diseases such as atherosclerosis and dementia [30]. While biologically plausible, increased number of committed CD8+ T-cells may not always be detrimental [31] or the sole basis for age-related risk of infections with long-term CMV seropositivity.

There are potential limitations of the study. As with challenges inherent to any registry-based studies, data items may have been missing or misclassified. CMV viremia and disease were not examined in this study as OPTN database does not include these data. However, this does not impact the study findings since the associations reported are in context of CMV serostatus regardless, of whether CMV viremia or disease developed in the patients. Although data on immunosuppressive regimens existed only for a subset of the patients in the registry database, rejection as a surrogate for intensity and net state of immunosuppression was incorporated in all analyses including multivariate and matched-control modeling. Given that Karnofsky performance scale is an observer assessed instrument, determination of functional status may be subject to bias and interobserver variability in general [32] or across different centers in the UNOS database [33] and assessments by health care providers may differ from those by the patients [34]. As such our findings should be considered hypothesis-generating and replicated using measures with greater construct validity and interrater reliability. We also caution that deaths may be multifactorial or unmeasured variables may have had a contributory role.

Strengths of the study are use of a systematically structured and comprehensive database comprising a large sample size that may not be logistically attainable outside the setting of a registry-based platform, with extended and long-term follow-up of the patients. As opposed to single center reports, the data include the entire US transplant population in real-world setting and depict routine clinical practices which enhances generalizability of the findings. Rigorous adjustment for contributory factors and other determinants minimizes their potential confounding effects on the relationship between CMV serostatus and the outcomes examined.

There are wide research and clinical implications of this study. Findings of our study open prospects to examine the immunological and inflammatory mediators by which CMV seropositivity contributes to inferior outcomes many years after transplantation. Identifying and targeting these pathways could pave the way for effective strategies for improving outcomes. The field of immune response modifiers and vaccines for CMV prophylaxis is moving at a fast pace. Whether these agents could provide enduring protection against downstream effects of CMV seropositivity, remains to be determined. Regardless, consideration should be given to assessment of functional outcomes in antiCMV trials not only at 12 months but also longer-term.

In summary, our study is the first evidence-based demonstration in a large population of liver transplant recipients within the last decade that CMV seropositivity in the donor or recipient was associated with significantly lower functional status at post-transplant and higher risk of deaths due to infections. Future studies are warranted to examine the mechanistic basis of these findings.

Author Contributions: Data curation, N.S. and M.M.W.; Formal analysis, N.S. and M.M.W.; Writingreview \& editing, N.S. and M.M.W. All authors have read and agreed to the published version of the manuscript.

Funding: The authors declare no funding was received for this study. 
Institutional Review Board Statement: Institutional review board of the VA Pittsburgh Healthcare System approved the study under exempt category as the dataset included publicly available deidentified data.

Informed Consent Statement: Not applicable.

Data Availability Statement: The OPTN database is a publicly available database.

Conflicts of Interest: The authors declare no conflict of interest.

$\begin{array}{ll}\text { Abbreviations } \\ \text { CMV } & \text { Cytomegalovirus } \\ \text { CI } & \text { Confidence interval } \\ \text { D } & \text { Donor } \\ \text { HCV } & \text { Hepatitis C virus } \\ \text { HHS } & \text { Department of Health and Human Services } \\ \text { HR } & \text { Hazard ratio } \\ \text { NASH } & \text { non-alcoholic steatohepatitis } \\ \text { NK } & \text { Natural killer cells } \\ \text { MELD } & \text { Model for End stage Liver Disease } \\ \text { OPTN } & \text { Organ Procurement and Transplantation Network } \\ \text { R } & \text { Recipient } \\ \text { RRT } & \text { renal replacement therapy } \\ \text { STAR } & \text { Standard Transplant Analysis and Research } \\ \text { UNOS } & \text { United Network of Organ Sharing }\end{array}$

\section{References}

1. 2018 Annual Report of the U.S. Organ Procurement and Transplantation Network and the Scientific Registry of Transplant Recipients: Transplant Data 2007-2018. Available online: https://srtr.transplant.hrsa.gov/annual_reports/2018/Liver.aspx (accessed on 8 July 2021).

2. Wieland, A.; Kohli, R. Non-Alcoholic Steatohepatitis as a Growing Indication for Liver Transplantation: The Evolving Gender and Ethnic Trends. Am. J. Gastroenterol. 2018, 113, 1588-1589. [CrossRef]

3. de Otero, J.; Gavaldà, J.; Murio, E.; Vargas, V.; Calicó, I.; Llopart, L.; Rosselló, J.; Margarit, C.; Pahissa, A. Cytomegalovirus disease as a risk factor for graft loss and death after orthotopic liver transplantation. Clin. Infect. Dis. 1998, 26, 865-870. [CrossRef]

4. Wang, G.C.; Kao, W.H.L.; Murakami, P.; Xue, Q.-L.; Chiou, R.B.; Detrick, B.; McDyer, J.F.; Semba, R.D.; Casolaro, V.; Walston, J.D.; et al. Cytomegalovirus infection and the risk of mortality and frailty in older women: A prospective observational cohort study. Am. J. Epidemiol. 2010, 171, 1144-1152. [CrossRef]

5. Aiello, A.E.; Haan, M.N.; Pierce, C.M.; Simanek, A.M.; Liang, J. Persistent infection, inflammation, and functional impairment in older Latinos. J. Gerontol A Biol. Sci. Med. Sci. 2008, 63, 610-618. [CrossRef]

6. Thomasini, R.L.; Pereira, D.S.; Pereira, F.S.M.; Mateo, E.C.; Mota, T.N.; Guimarães, G.G.; Pereira, L.S.M.; Lima, C.X.; Teixeira, M.M.; Teixeira, A.L. Aged-associated cytomegalovirus and Epstein-Barr virus reactivation and cytomegalovirus relationship with the frailty syndrome in older women. PLOS ONE 2017, 12, e0180841. [CrossRef]

7. Samson, L.D.; Berg, S.P.V.D.; Engelfriet, P.; Boots, A.M.; Hendriks, M.; De Rond, L.G.; De Zeeuw-Brouwer, M.; Verschuren, W.M.; Borghans, J.A.; Buisman, A.; et al. Limited effect of duration of CMV infection on adaptive immunity and frailty: Insights from a 27-year-long longitudinal study. Clin. Transl. Immunol. 2020, 9, e1193. [CrossRef]

8. Whiting, C.C.; Siebert, J.; Newman, A.M.; Du, H.-W.; Alizadeh, A.A.; Goronzy, J.; Weyand, C.M.; Krishnan, E.; Fathman, C.G.; Maecker, H.T. Large-Scale and Comprehensive Immune Profiling and Functional Analysis of Normal Human Aging. PLoS ONE 2015, 10, e0133627. [CrossRef]

9. McAdams-DeMarco, M.A.; Chu, N.M.; Segev, D.L. Frailty and Long-Term Post-Kidney Transplant Outcomes. Curr. Transpl. Rep. 2019, 6, 45-51. [CrossRef] [PubMed]

10. McAdams-DeMarco, M.A.; Ying, H.; Olorundare, I.; King, E.A.; Haugen, C.; Buta, B.; Gross, A.L.; Kalyani, R.; Desai, N.M.; Dagher, N.; et al. Individual Frailty Components and Mortality in Kidney Transplant Recipients. Transplantation 2017, 101, 2126-2132. [CrossRef] [PubMed]

11. Bui, K.; Kilambi, V.; Rodrigue, J.R.; Mehrotra, S. Patient Functional Status at Transplant and Its Impact on Posttransplant Survival of Adult Deceased-donor Kidney Recipients. Transplantation 2019, 103, 1051-1063. [CrossRef] [PubMed]

12. Garonzik-Wang, J.M.; Govindan, P.; Grinnan, J.W.; Liu, M.; Ali, H.M.; Chakraborty, A.; Jain, V.; Ros, R.L.; James, N.T.; Kucirka, L.M.; et al. Frailty and delayed graft function in kidney transplant recipients. Arch. Surg. 2012, 147, 190-193. [CrossRef] [PubMed] 
13. Lentine, K.L.; Alhamad, T.; Cheungpasitporn, W.; Tan, J.C.; Chang, S.-H.; Cooper, M.; Dadhania, D.M.; Axelrod, D.A.; Schnitzler, M.A.; Ouseph, R.; et al. Impact of Functional Status on Outcomes of Simultaneous Pancreas-kidney Transplantation: Risks and Opportunities for Patient Benefit. Transpl. Direct 2020, 6, e599. [CrossRef]

14. Dolgin, N.H.; Martins, P.N.; Movahedi, B.; Lapane, K.L.; Anderson, F.A.; Bozorgzadeh, A. Functional status predicts postoperative mortality after liver transplantation. Clin. Transpl. 2016, 30, 1403-1410. [CrossRef] [PubMed]

15. Grimm, J.C.; Valero, V., 3rd; Kilic, A.; Crawford, T.C.; Conte, J.V.; Merlo, C.A.; Shah, P.D.; Shah, A.S. Preoperative performance status impacts perioperative morbidity and mortality after lung transplantation. Ann. Thorac Surg. 2015, 99, 482-489. [CrossRef] [PubMed]

16. Kilic, A.; Beaty, C.A.; Merlo, C.A.; Conte, J.V.; Shah, A.S. Functional status is highly predictive of outcomes after redo lung transplantation: An analysis of 390 cases in the modern era. Ann. Thorac Surg. 2013, 96, 1804-1811. [CrossRef] [PubMed]

17. Haugen, C.E.; McAdams-DeMarco, M.; Verna, E.C.; Rahimi, R.S.; Kappus, M.R.; Dunn, M.A.; Volk, M.L.; Gurakar, A.; Duarte-Rojo, A.; Ganger, D.R.; et al. Association Between Liver Transplant Wait-list Mortality and Frailty Based on Body Mass Index. JAMA Surg. 2019, 154, 1103-1109. [CrossRef] [PubMed]

18. Mor, V.; Laliberte, L.; Morris, J.N.; Wiemann, M. The Karnofsky Performance Status Scale. An examination of its reliability and validity in a research setting. Cancer 1984, 53, 2002-2007. [CrossRef]

19. Reese, P.P.; Shults, J.; Bloom, R.D.; Mussell, A.; Harhay, M.N.; Abt, P.; Levine, M.; Johansen, K.L.; Karlawish, J.T.; Feldman, H.I. Functional status, time to transplantation, and survival benefit of kidney transplantation among wait-listed candidates. Am. $J$. Kidney Dis. 2015, 66, 837-845. [CrossRef]

20. Reese, P.P.; Bloom, R.D.; Shults, J.; Thomasson, A.; Mussell, A.; Rosas, S.E.; Johansen, K.L.; Abt, P.; Levine, M.; Caplan, A.; et al. Functional status and survival after kidney transplantation. Transplantation 2014, 97, 189-195. [CrossRef]

21. Taylor-Wiedeman, J.; Sissons, P.; Sinclair, J. Induction of endogenous human cytomegalovirus gene expression after differentiation of monocytes from healthy carriers. J. Virol. 1994, 68, 1597-1604. [CrossRef]

22. Kurz, S.K.; Reddehase, M.J. Patchwork pattern of transcriptional reactivation in the lungs indicates sequential checkpoints in the transition from murine cytomegalovirus latency to recurrence. J. Virol. 1999, 73, 8612-8622. [CrossRef]

23. Souquette, A.; Frere, J.; Smithey, M.; Sauce, D.; Thomas, P.G. A constant companion: Immune recognition and response to cytomegalovirus with aging and implications for immune fitness. Geroscience 2017, 39, 293-303. [CrossRef] [PubMed]

24. Polansky, H.; Javaherian, A. The latent cytomegalovirus decreases telomere length by microcompetition. Open Med. Wars 2015, 10, 294-296. [CrossRef] [PubMed]

25. Dowd, J.B.; Bosch, J.A.; Steptoe, A.; Blackburn, E.H.; Lin, J.; Rees-Clayton, E.; Aiello, A.E. Cytomegalovirus is associated with reduced telomerase activity in the Whitehall II cohort. Exp. Gerontol. 2013, 48, 385-390. [CrossRef]

26. Dowd, J.B.; Bosch, J.A.; Steptoe, A.; Jayabalasingham, B.; Lin, J.; Yolken, R.; Aiello, A.E. Persistent Herpesvirus Infections and Telomere Attrition Over 3 Years in the Whitehall II Cohort. J. Infect. Dis. 2017, 216, 565-572. [CrossRef]

27. Aiello, A.E.; Haan, M.; Blythe, L.; Moore, K.; Gonzalez, J.M.; Jagust, W. The influence of latent viral infection on rate of cognitive decline over 4 years. J. Am. Geriatr. Soc. 2006, 54, 1046-1054. [CrossRef]

28. Pawelec, G.; Koch, S.; Franceschi, C.; Wikby, A. Human immunosenescence: Does it have an infectious component? Ann. N Y Acad Sci. 2006, 1067, 56-65. [CrossRef] [PubMed]

29. Fülöp, T.; Larbi, A.; Hirokawa, K.; Mocchegiani, E.; Lesourd, B.; Castle, S.; Wikby, A.; Franceschi, C.; Pawelec, G. Immunosupportive therapies in aging. Clin. Interv. Aging. 2007, 2, 33-54. [CrossRef]

30. Franceschi, C.; Bonafe, M.; Valensin, S. Human immunosenescence: The prevailing of innate immunity, the failing of clonotypic immunity, and the filling of immunological space. Vaccine 2000, 18, 1717-1720. [CrossRef]

31. Fulop, T.; Larbi, A.; Dupuis, G.; Fulop, T.; Larbi, A.; Dupuis, G.; Le Page, A.; Frost, E.H.; Cohen, A.A.; Witkowski, J.M.; et al. Immunosenescence and Inflamm-Aging As Two Sides of the Same Coin: Friends or Foes? Front. Immunol. 2017, 8, 1960. [CrossRef] [PubMed]

32. Kelly, C.M.; Shahrokni, A. Moving beyond Karnofsky and ECOG Performance Status Assessments with New Technologies. J. Oncol. 2016, 2016, 6186543. [CrossRef] [PubMed]

33. Wang, C.W.; Lai, J.C. Reporting functional status in UNOS: The weakness of the Karnofsky Performance Status Scale. Clin. Transplant. 2017, 31, e13004. [CrossRef] [PubMed]

34. Ando, M.; Ando, Y.; Hasegawa, Y.; Shimokata, K.; Minami, H.; Wakai, K.; Ohno, Y.; Sakai, S. Prognostic value of performance status assessed by patients themselves, nurses, and oncologists in advanced non-small cell lung cancer. Br. J. Cancer 2001, 85, 1634-1639. [CrossRef] [PubMed] 